Bryant University

Bryant Digital Repository

English and Cultural Studies Journal Articles

English and Cultural Studies Faculty

Publications and Research

Winter 2020

\title{
Asking for It: Rape Myths, Satire, and Feminist Lacunae
}

Viveca S. Greene

Hampshire College

Amber Day

Bryant University, aday@bryant.edu

Follow this and additional works at: https://digitalcommons.bryant.edu/eng_jou

Part of the Feminist, Gender, and Sexuality Studies Commons, and the Other Arts and Humanities Commons

\section{Recommended Citation}

Greene, Viveca S. and Day, Amber, "Asking for It: Rape Myths, Satire, and Feminist Lacunae" (2020). English and Cultural Studies Journal Articles. Paper 91.

https://digitalcommons.bryant.edu/eng_jou/91

This Article is brought to you for free and open access by the English and Cultural Studies Faculty Publications and Research at Bryant Digital Repository. It has been accepted for inclusion in English and Cultural Studies Journal Articles by an authorized administrator of Bryant Digital Repository. For more information, please contact dcommons@bryant.edu. 


\section{Asking for It: Rape Myths, Satire, and Feminist Lacunae}

H

ow we talk about sexual assault matters. Language and framing help construct our understanding of any issue, but particularly one as fraught as sexual violence. At any given time, wildly different frameworks of any culturally contested topic compete with one another. Following revelations of years of sexual assault by film producer Harvey Weinstein, the outpouring of allegations against other powerful men and the flood of \#MeToo testimonials have helped to at least temporarily shift the mainstream conversation a little closer to a feminist frame. The public spectacle around sexual harassment may have finally demonstrated to many onlookers that there is indeed a systemic problem-though that assumption is vehemently disputed in some circles.

One area in which this concern is particularly visible is in the world of comedy and performance. Changing industry practices, including the fragmentation of media outlets and the development of narrowcasting (aiming television programming at small niche audience groups, as opposed to the previous "broadcast" model), have led to a greater number of high-profile female comedians and producers. With that shift has come new perspectives, and with them an interest in exposing rape culture, as performers are moving past offensive jokes about rape that target victims and instead are drawing attention to the systemic forces that encourage sexual violence. Rape culture refers to societal norms that promote stereotypes about rape and rape survivors, as well as other "cultural practices ... that excuse or otherwise tolerate sexual violence" (Ridgeway 2014). The concept has become a flash point for conservatives - and in particular adherents of the alt-right - who are often "inspired and defined by a discourse of anxiety about traditional white masculinity, which is seen as being artificially but powerfully 'degenerated,' with catastrophic consequences for the nation” (Kelly 2017, 69). Unabashedly outspoken female performers, especially those of color, often find

We wish to thank McKenzie Armstrong, Maggie Ellis, Kirsten Leng, Megan Lewis, Lise Sanders, and Nancy Wadsworth for their indispensable contributions to this article. Many thanks also to our anonymous reviewers for their thought-provoking and productive feedback, and to Miranda Outman for her thorough and gracious edits. 
themselves the objects of vitriolic online attacks simply for having a platform and particularly when they address structures of power.

Nevertheless, female-identified comics and performers employ satire to challenge long-ingrained cultural truisms like rape myths, including the belief that women are often "asking for it" through their behavior (style of dress, alcohol consumption, etc.) and the assumption that women routinely invent charges of sexual assault to punish men. They also address how political, educational, and cultural institutions perpetuate such myths and rape culture more broadly. Even prior to 2017's deluge of rape and sexual violence cases, women satirists were, we contend, part of a larger cultural battle that bubbled to the surface in widely publicized cases such as the gang rape committed by students in Steubenville, Ohio; violent threats against the women targeted in the online harassment campaign known as GamerGate; and the coordinated misogynist campaign against the 2016 reboot of Ghostbusters.

As Jessyka Finley (2016) maintains, "Performance comedy and mainstream electoral politics alike are professions and discursive fields dominated by white men, who always have ready access to the stump" (242). Indeed, the battle against rape culture is currently taking place under the presidency of Donald Trump, who was caught on audio instructing Billy Bush to "Grab 'em by the pussy. You can do anything" (Bullock 2016, 19). In his New York Times editorial fifteen years after the fact, Bush explained that he and the others on the Access Hollywood bus "assumed we were listening to a crass standup act . . surely, we thought, none of this was real" (2017). Bush's belief that comedy and reality are distinct entities is a dubious assumption. As research suggests, exposure to sexist humor increases tolerance for discrimination against women (Ford 2000), and there are significant correlations between sexist humor, sexual harassment, discrimination, and tolerance for sexual violence and rape proclivity (Ford et al. 2008; Romero-Sánchez et al. 2010; Thomae and Viki 2013).

Just as rape jokes help constitute rape culture, we contend that jokes and satirical performances that confront aspects of that culture are vital to challenging it. In contrast to comedy legend Jerry Seinfeld, who claims to "have no interest in gender or race or anything like that" as such jokes are "anticomedy" and "PC nonsense" (quoted in Jones 2014), we consider the contributions of three feminist performers in reinvigorating satire, disrupting the association of feminists as humorless, and participating in the larger cultural battle over sexual violence. Samantha Bee and Amy Schumer-the creators, hosts, and executive producers of two popular comedy shows - critique dimensions of rape culture on their programs, and Lena Weissbrot - an undergraduate student at Florida State University - satirizes rape culture in an independently produced music video. 
Feminist analyses of popular culture tend either to ignore problematic racial dimensions of a given text or to acknowledge them but nevertheless claim the text as feminist. In the pages that follow, we strive to avoid such tendencies. Our three white-presenting satirists do not always or equally evince an understanding of the centuries-old relationship between rape culture and racism; at times they reinforce or perpetuate a cultural silence about the ideologies that underpin and inform both. There is thus a tension between our examination of feminist comedians' reinvigoration of satire through work on rape culture and how they are participating in a particular version of white feminism: one that ignores intersectionality and often neglects the politics and history of racism in this country. This is a tension we seek to highlight rather than elide. Through critical contextual analysis, in this article we explore three performers' satirical critiques of rape culture in which history, feminism, toxic masculinity, racism, and privilege are both revealed and obscured.

\section{Satire, "angry feminists," and rape culture}

Satire is the most politically focused form of humor or art. As George Test defines it, satire involves four crucial elements: aggression, judgment, laughter, and play $(1991,14)$. As a form of criticism, it is most often used to point out social or political hypocrisies and inconsistencies. It has the ability to deconstruct official language and policy, as well as to shame those behind the language. Jonathan Gray, Jeffrey Jones, and Ethan Thompson explain, "Satire's calling card is the ability to produce social scorn or damning indictments through playful means, and in the process, transform the aggressive act of ridicule into the more socially acceptable act of rendering something ridiculous" $(2009,13)$. And through collective laughter, satire can also help build a sense of community for those in on the joke. As such, it can be a powerful tool for those, such as feminists, who wish to challenge oppressive ideologies, to change the terms we use to conceptualize an issue, or to push otherwise niche issues into the mainstream.

According to Peg Brand (2006), "A feminist satire is a work of art that expresses a woman's point of view as it makes fun of prevailing artistic conventions and societal norms established by men" (180). One impediment that has long stood in the way of feminists using satire and other forms of critical comedy, however, has been the deep-rooted cultural stereotype that feminists are by nature angry, humorless killjoys: women too serious and sensitive to get a joke, let alone tell one. Popular culture has long depicted the movement as militant, extreme, and irrationally angry. As Barbara Tomlinson explains, "angry feminist" is a trope that is "designed to delegitimize feminist argument even before the argument begins, to undermine feminist 
politics by making its costs personal, and to foreclose feminist futures by making feminism seem repulsive to young women" $(2010,1)$. As a trope, it is used to conjure emotions and judgments without having to put forward any evidence, "interpellating readers as always already antifeminist" (1). Indeed, in 2016, over four in ten Americans polled still saw the movement as angry, and a similar portion said it unfairly blames men for women's challenges (Cai and Clement 2016).

Despite the popular belief that feminism is humorless and unfun, and Christopher Hitchens's oft-cited declaration that "women aren't funny" (2007), women comedians who identify as feminists are more visible in popular culture than ever before. As Linda Mizejewski contends, "Women's comedy has become a primary site in mainstream pop culture where feminism speaks, talks back, and is contested" $(2014,6)$. Rape and rape culture have long been issues of concern to feminists across identity coordinates, so it is perhaps unsurprising that female comedians are now muscling the topic onto television screens and into comedy clubs.

Theorists of rape culture argue that to address the impact of sexual violence, society must shift from understanding it solely as an act involving individuals to seeing it as an issue rooted in social and cultural relations and expectations. The contributions of rape jokes to rape culture are of particular significance to our analysis. Karrin Anderson (2012) argues that accepting jokes about sexual assault is a central component of rape culture: "Rape is invoked as entertainment, dismissed as 'horsing around,' and deployed as a weapon. . . . Rape culture first desensitizes, then degrades, and finally dehumanizes its subjects, prompting regular people to blithely laugh at rape jokes." In their interviews with undergraduate students about sexist and racist humor and rape jokes, Raúl Pérez and Viveca Greene (2016) found evidence of Anderson's claim, particularly with regard to desensitization. However, as Pérez, Greene, and other scholars note, not all jokes about rape and sexual assault target victims/survivors.

For example, in her comedy special Wanda Sykes: Sick and Tired (2006), Wanda Sykes draws attention to the prevalence of rape and its impact on women's everyday lives: "Wouldn't it be wonderful if our pussies were detachable? .. Just think of the freedom that you would have! You get home from work, it's getting a little dark outside. You're like: 'Oh, I would like to go for a jog, but. ... It's getting too dark! ... Oh! I'll just leave it at home! ...' If some crazy guy jumps out the bushes like 'AAH!' you're like 'I left it at home! . . . Sorry! I have absolutely nothing of value on me. I'm pussy-less!' ” Read as satiric commentary, Sykes's routine addresses how the prevalence of rape curtails the freedom of anyone with a vagina (or anyone suspected to 
have one) to go about daily life without risking sexual assault. As Bambi Haggins explains, Sykes, as well as earlier comedy pioneer Moms Mabley, "used their lived experiences of being marginalized . . . to speak truth to power" $(2017,229)$. That sort of nuance, however, is often missing from discussions about sexual violence.

As Debra Ferreday (2015) contends, rape culture is "a complex social phenomenon that is not limited to discrete criminal acts perpetrated by a few violent individuals but is the product of gendered, raced and classed social relations that are central to patriarchal and heterosexist culture" (22). The history of antirape feminist work is marred by racism, as is the history of white feminism itself. As Angela Davis (1983) and Kimberlé Crenshaw (1989) argue, Susan Brownmiller, who first employed the term rape culture, was among second-wave white antirape feminist theorists who "assert[ed] that Black men are motivated in especially powerful ways to commit sexual violence against women" (Davis 1983, 180-81). Through such theories, the women of color who have been subjected to sexual violenceby white men - throughout history are largely overlooked. Representations of black men as rapists have resulted in lynchings and disproportionate incarceration rates, and women of color who are raped are often discredited and stereotyped as promiscuous.

Drawing on the work of bell hooks, George Yancy (2000) notes that "whiteness, within the feminist movement, has assumed a position of absolute authority, speaking from a center which marginalizes non-white voices" (158). White women's prominent/dominant roles in the mainstream feminist movement are not a recent development. An ongoing debate within feminist organizations and among activists is "about the continued exclusion of nonwhite women from mainstream feminism" (Loza 2014; emphasis added). Furthermore, black feminists often remain "forced to pick between being politically black or politically female" (Okeowo 2017). As Crenshaw (1989) explains with regard to rape-related issues: "Black women are caught between a Black community that, perhaps understandably, views with suspicion attempts to litigate questions of sexual violence, and a feminist community that reinforces those suspicions by focusing on white female sexuality. The suspicion is compounded by the historical fact that the protection of white female sexuality was often the pretext for terrorizing the Black community" (159-60).

The term intersectionality has recently become a buzzword, especially after the 2017 Women's March on Washington, when it "became the go-to word to explain the aims and goals of the March" (Stamper 2018). Crenshaw, who coined the term in 1989, explains that "intersectionality is a lens through 
which you can see where power comes and collides, where it interlocks and intersects. It's not simply that there's a race problem here, a gender problem here, and a class or LBGTQ problem there. Many times that framework erases what happens to people who are subject to all of these things" (Crenshaw 2017). Single-axis analyses of power lead to "limiting inquiry to the experiences of otherwise-privileged members of the group" (Crenshaw 1989, 140). Mainstream feminist critiques often begin with the experiences of white women - that is, by centering whiteness - and then attempt to "fold in" other women who experience intersectional oppression. This tendency undermines efforts to broaden feminist antiracist analysis.

Below, we explore the work of three white-presenting feminist-identified satirists and their strategies for addressing rape culture. In particular, we attend to the institutional and cultural targets of their critiques, the audiences they address, the pleasures they offer their receptive viewers, the anger they elicit from other audiences, and their contributions to larger cultural conversations about rape culture. We also suggest what is absent from their critiques, especially with regard to the racial politics of rape culture. We critique these performances both with the understanding that there will inevitably be blind spots in comedians' work and with the knowledge that those who satirize rape culture can reproduce single-axis analyses of it, as well as reinscribe attendant rape myths, even as they labor to desconstruct some of those myths. Our project is to explore how Bee, Schumer, and Weissbrot address sexual violence, to consider some of the backlash to their work, and to reflect critically about the possibilities and limitations of their performances.

\section{Samantha Bee: Politics, angry feminism, and colorblind rape culture}

After making a name for herself as a correspondent on The Daily Show with Jon Stewart, Samantha Bee debuted her own show, Full Frontal with Samantha Bee, in early 2016. With executive producer Jo Miller, Bee set up a blind process for hiring writers that hid the gender and experience level of applicants and succeeded in producing the most diverse writers' room in late-night comedy: roughly half female and 30 percent nonwhite (Traister 2016). Granted a platform on Full Frontal as an already famous middle-class white woman, Bee cedes the mic to writer and correspondent Ashley Nicole Black, who is African American, on issues that primarily impact black communities, for instance in segments about the history of blackface minstrelsy or on the Black Lives Matter movement. In addition to covering the same stories in the news cycle as other late-night hosts, Bee and her team frequently create lengthy pieces on otherwise more obscure national and international news stories, many of 
which focus on a particular injustice or indignity, often one related to gender inequality.

Developing a signature style of hilariously embellished curses and insults, Bee takes aim at the way outspoken women in the public eye are clearly threatening to many, resulting in routine barrages of vicious slurs and threats of (often sexual) violence, a harassment phenomenon Karla Mantilla (2013) dubs "gendertrolling": "patrolling gender boundaries and using insults, hate, and threats of violence and/or rape to ensure that women and girls are either kept out of, or play subservient roles in, male-dominated arenas" (568). Even prior to Full Frontal's first airing, Bee addressed the amassing trolls by setting up a rape-threat hotline, which she discussed in much of the preshow publicity. Callers to the hotline heard the recorded message "Hello, you have reached the Samantha Bee Rape Threatline. Nobody's here to answer your call, but your offer of non-consensual sex is important to us, so please select from the following menu" (Burton 2015). Options included "to tell me I'm a dumb bitch that needs to be raped, press I" and "to tell me you're going to violate every hole in my idiot libtard body, press 2 " (Burton 2015). Hearing these all-too-common internet comments spoken out loud amid the chatter of prepublicity talk show interviews drew attention to a virulent form of misogyny easily ignored because of its location on the fringes of mainstream discourse.

Another recurring theme has been the response of political and legal institutions to sexual violence. Early in the show's run, for instance, Bee shone a spotlight on the backlog of rape test kits across the country. Drawing on a variety of news clips, in the sketch she explains that there are thousands of used but untested rape kits collecting dust in police storage rooms and, in some locales, the stockpiled kits can be destroyed. The good news, she informs us, is that some states have begun passing bipartisan laws to "chip away at Rape Evidence Mountain, because catching rapists is the one thing everyone can agree on. .. Well, almost everyone" (Full Frontal 2016). She then zeroes in on a proposed Georgia law mandating testing for rape kits that was passed unanimously by the Georgia house but was killed by the state senator chairing the corresponding committee, who didn't believe the issue was really a problem. Incredulous, Bee wonders if the senator is in the pocket of "Big Rape" because, alluding to Georgia's patriarchal and white supremacist history, "if the confederate clown car that is the Georgia House can come together on this bill, who are you to block it?" (Full Frontal 2016).

However, Bee saves her most savage attacks for a sheriff in Idaho who publicly argued against similar laws, playing a tape of him claiming that most rape victims are not "real victims"; rather, they are simply experiencing regret 
about their choices. To the taped comments Bee responds by addressing the sheriff as an animal, simultaneously infantalizing him and turning rape myths back on him individually: "Listen, you giant pink hamster fetus of a man, ... you can believe women are lying whores all you want when you are off the clock, but when you are the sheriff, you have to listen to rape victims. Otherwise when the women in your county rise up and strangle you with your own stupid monogrammed shirt, it's going to be consensual assisted suicide, because you are definitely asking for it" (Full Frontal 2016). Bee explains that most rapists are serial rapists and that states that have tested their kits have caught many repeat offenders. She concludes by pointing out that the senator and sheriff are both running unopposed in upcoming elections, quipping, "Local elections are a lot like rape kits. No one really wants to pay attention to them, but if you bother to open them up, you might just get rid of someone who has been screwing everyone in town." Bee first uses her satire to shame these public figures and then suggests concrete action some viewers might take to punish them.

The piece attracted its own news coverage, likely because Bee pointed fingers at particular public figures and highlighted the moral imperative of ensuring the processing of the kits. When the Georgia bill mandating the testing of all rape kits eventually did pass (also chronicled on the show), some pointed to Bee's coverage as a catalyst (Vanstone 2017). It stands out as an example of a comedian strategically using her platform and evidencebased comedy to effect change, drawing attention to an issue worthy of outrage, detailing rational solutions, and allowing citizen-viewers to apply pressure. The rape-kit segment highlighted elements of rape culture that can be easily obscured, such as the way that victims are routinely doubted by those in positions of authority and the assumption that only promiscuous women get raped.

Bee does not indicate what she believes the consequences or punishment should be for those implicated by rape kit tests. Although the "Rape Kit Backlog" sketch might lead viewers to conclude that the solution to rape culture is to round up and incarcerate rapists, we should be critical of such thinking, as the mass-incarceration state does not address the underlying causes of most crime, including rape, or of rape culture, and its racial bias has been amply documented (Levitz 2016). It also warrants mention that women of color's experiences with institutionalized racism, including law enforcement and social service agencies, add to the list of deterrents to reporting that all survivors face by eroding trust in "the systems and institutions that are supposed to help them" (Connecticut Alliance to End Sexual Violence, n.d.). However, rape kit testing can help clear or exonerate people wrongly accused of - or charged with — rape, such as the black and Latino males known 
as the Central Park Five, and it can support the victims most likely to be raped and experience institutional indifference: those who identify as LGBTQ+ and women of color (Schmiedt and Roth 2015; Human Rights Campaign, n.d.).

Given the complexity of these issues, especially with regard to the multiple axes of oppression at play here, discussion of rape culture is difficult comedic territory. Further, for even the most privileged women, to reference inequality with any hint of anger is to face overwhelming pushback, as evinced by responses to Bee's show. It is little wonder, then, that female politicians and entertainers often work hard to be viewed as anything but angry, while many eschew the label of feminist. Yet Bee does precisely the opposite, and her anger and conviction are what most strikingly sets Full Frontal apart from anything else on American television, where strident feminism is almost unheard of. She self-consciously presents herself as an impassioned feminist and in so doing interpellates her audience as also already feminist, assuming that they will be as outraged as she at institutional sexism that negatively impacts women from a wide range of identity groups. For like-minded audience members, there is undoubtedly satisfaction in hearing a feminist perspective-albeit a white, middle-class, cisgender, and able-bodied one-articulated on television, sexual assault addressed explicitly, and her profanity-laden take-downs of people and policies so deserving of scorn. Amid the laughter and cheers of her audience, Bee creates the feeling that viewers are all in the battle to right some wrongs together, united in our outrage against inept officials, sexist policy making, and outdated norms, and in our pleasure in using laughter to mock those who act against the public interest. Bee is not about to be silenced or allow like-minded women to be, especially by trolls, whom she trolls right back. Bee reclaims feminism and feminist anger, and in so doing educates her audience about feminist issues, underscores the importance of taking action and speaking out (for those in safe enough positions to do so), and demonstrates the power of satire to challenge oppressive institutions and ideologies.

In other notable segments on sexual violence, Bee variously diagrams the type of sexual harassment practiced by Donald Trump and Billy Bush on the Access Hollywood bus, creates a facetious public service announcement for male executives on how to resist masturbating in front of their employees, and champions a bill sponsored by US Senator Kirsten Gillibrand that would make it easier for military employees to report sexual assault without suffering retaliation. Bee's focus in these segments is often on concrete steps that could be taken to remedy problems. As Todd VanDerWerff (2016) notes, white male late-night hosts such as Jon Stewart and John Oliver present information pertaining to injustice as interesting rather than vital, as intractable rather than imperative to act on. However, as VanDerWerff contends, from Full Frontal's outset, Bee offered “a blanket condemnation of an entire 
political system where everybody is lazily comfortable with their privilege." Bee aims to get her audience riled up. She attacks hypocrisy and political gamesmanship, and she offers clear pathways for remedial action: most often pressuring local officials or even running for office oneself.

Bee's focus tends to be on the ways rape culture is baked into the legal and political system for all survivors of sexual assault and less on the significance of racial identity or sexual orientation to sexual violence. On this particular issue, Bee adopts what might be regarded as a "colorblind feminist" approach to addressing rape culture (Bell 2016). Nevertheless, the racial politics of her oeuvre is in many ways commendable, especially in terms of her diverse writing staff and often spot-on critiques of whiteness and privilege. Her brand of satire is also less racially divisive than the next two performers we examine, and her choices with regard to the show as a whole indicate a commitment to further addressing the social context of rape culture as a complex phenomenon.

\section{Amy Schumer: Everyday rape culture, white feminism, and hipster racism}

Amy Schumer began her career as a stand-up comedian, eventually securing her own sketch comedy program on Comedy Central, Inside Amy Schumer (2013-present) and subsequently starring in several movies. Schumer's signature style involves explicitly dirty humor and self-reported bad behavior, delivered with feigned naïveté and girlish innocence. Onscreen Amy often inhabits white female stereotypes, though the irony of the text, or dialogue, works to dismantle them. ${ }^{1}$ As Dustin Bradley Goltz (2015) observes, her ironic mode of performativity "continually plays with and against sexist expectations of politeness, cuteness, and white feminine modes of accommodation" (273). It is a style that has enabled her to find success on the male-heavy Comedy Central network while also attracting plaudits for her skewering of misogyny. Season 3's audience was 63 percent male on average, just four points lower than the network norm (Handy 2016). Slate's Willa Paskin (2014) refers to the program as "sneakily feminist," arguing that "by wrapping her ideas in a ditzy, sexy, slutty, self-hating shtick, [Schumer's] message goes down easy - and only then, like the alien, sticks its opinionated teeth into you." The "you" here is presumably the nonfeminist viewer of

\footnotetext{
${ }^{1}$ As Samantha Bee seems to be playing herself as the host of her show, we refer to her as "Bee." When Amy Schumer plays a character in her sketch comedy, she isn't necessarily playing herself (but rather the "dumb white girl character"), so we refer to her as "Amy" in those instances and as "Schumer" when referring to her outside of sketch comedy (e.g., her tweets).
} 
any gender, and this “sneakiness" is undoubtedly tied to Schumer's on-camera persona, which, as Paskin suggests, is oblivious rather than angry. However, Schumer's oblivious persona at times includes (questionably) ironic bigotry, and her reaction to related criticism has done little to improve her credibility as an intersectional feminist.

Schumer's comedy about white, heterosexual, cisgender norms can be insightful, particularly in sketches addressing the "bro culture" that is particularly vibrant in institutions that promote toxic masculinity such as the military, sports, video gaming, and fraternities. She has produced several sketches that shine a harsh spotlight on elements of rape culture. One such sketch ("A Very Realistic Military Game") opens with Amy deciding to take a turn at her boyfriend's military-style video game, commenting "oh, cool, I can be a girl [character]" (Inside Amy Schumer 2014). ${ }^{2}$ The boyfriend rolls his eyes and sarcastically responds, "Yeah ... knock yourself out," as he gets up for a beer. We then see her avatar blocked by a commander who tells her to hang back after dismissing the other soldiers, as the real Amy's face contorts with disbelief. When her boyfriend returns, she says "I think my character was just . . raped!" He responds "that's never happened to me; you must have pressed the wrong button." But her story is confirmed by the video game voice-over, and the boyfriend confusedly wanders away again to check the message boards. Despite the voice-over's discouragement, she chooses to report the assault and, after her avatar completes mountains of paperwork, she heads to court. At the trial, other characters reproduce rape myths, shouting things like "what were you wearing?" and "be a team player," after which the voice-over proclaims "character assassination complete." Finally, the voice-over announces that her attacker was found guilty in a military court, but his commanding officer chose to reject that decision, and he is now back on active duty. Amy begins swearing at the game in frustration, at which point her boyfriend returns, admonishing her language ("be a lady!") and declaring that he "checked the message boards and it doesn't say anything, so obviously you did something wrong. It is probably best you don't play." He takes the controller out of her hands and resumes his own game.

The sketch depicts military culture as replete with sexual violence and the military bureaucracy as impossibly stacked against rape victims. The misogyny of video gaming culture is likewise a target of critique, especially as the sketch zeroes in on more subtle cultural attitudes embodied in the character of the gamer boyfriend. He is presented as a generally likable guy, but he is so

\footnotetext{
${ }^{2}$ Comedy shows typically include multiple sketches per episode. Per convention, we have listed the first sketch of each episode in the reference list. Therefore, sketch titles discussed in the text may not correspond with the titles listed in the references.
} 
self-involved that he cannot recognize what's happening to his girlfriend or her avatar, neither of whom, as female, he seems to take seriously. When he is confronted with a reality that is foreign to him-being sexually assaultedhis knee-jerk reaction is rape denial: to dismiss the possibility that anything untoward could have taken place, choosing instead to blame the victim for doing something wrong. He is not just harmlessly clueless. Rather, he is cluelessly shoring up a system that perpetuates harm.

Another sketch on Inside Amy Schumer targets the intersections of rape culture and sports culture. Structured as a parody of NBC's long-running television program Friday Night Lights(2006-11), "Football Town Nights" (Inside Amy Schumer 2015) opens by drawing on some of the aesthetic elements of Friday Night Lights, including a filmic introductory montage of the small-town setting, thematic music, and a radio voice heard talking about the new football coach getting the boys ready for the upcoming game. When the coach meets his players and sternly lays down his ground rules, which include "no raping," the players are at first incredulous ("but coach, we play football"), then aghast, asking a litany of questions about situations they assume would count as an exception, such as "what if it is Halloween and she is dressed like a sexy cat?" and "what if she thinks it's rape, but I don't?" Although some of the questions are obviously ridiculous (including the numerous queries regarding sexy Halloween costumes), the sketch catalogs many of the myths used to excuse rape or blame the victim. It also critiques the social attitudes of ordinary people, pointing to how many (including women) work to uphold the status quo: as two elderly white women walking by the coach's house recognize him as "that new coach who don't like raping," asking how "our boys are supposed to celebrate when they win?" and spitting at his feet.

Finally, we see a game that is going badly, with a key player injured and the team falling behind. The coach angrily asks one particular player, "Dugan, what the hell were you thinking out there on that last play, son?" Dugan replies, "I was thinking about raping." This prompts the frustrated coach to launch into a cliché inspirational pep talk, though the content of the speech is decidedly ironic: "How do I get through to you boys that football isn't about rape, it is about violently dominating anyone that stands between you and what you want. You got to get yourself into the mindset that you are gods and you are entitled to this. That other team, they ain't just going to lay down and give it to you. You got to go out there and take it!" Though the coach wants to condemn the act of rape, he ends up unselfconsciously reinforcing rape culture, illustrating the "scoring" and entitlement attitudes underlying rape and football.

For those sympathetic to the messages of these sketches, there is pleasure (and perhaps catharsis) in hearing a critique of rape culture articulated in a 
mainstream venue and perhaps in having one's own interpersonal and/or institutional experiences affirmed. However, the YouTube comments under these sketches are telling. Although some post appreciative remarks, at least half of the commentators are angrily offended. Many insult Schumer's appearance or call her a slut, while others explicitly take umbrage at the sketches' implications. Under "Football Town Nights" in particular, the commentators angrily accuse the sketch of implying that all men are evil rapists. One commentator calls Schumer a "liberal feminist psycho" and tells her to "stop perpetuating the whole 'rape culture' agenda (and it is an agenda) because it simply isn't true." Though her feminism might seem "sneaky" to some, it appears strikingly apparent to those who hate feminism most. The alt-right movement has made Schumer a regular target for gender trolling, organizing members to trash the ratings for her comedy specials. For some audiences, even a heterosexual, cisgender, white female comedian who often performs a gendered "ditz" character (Goltz 2015, 272) violates the toxic male sense of ownership over the perceived sacred space of sports culture.

With a greater inclination to address interpersonal relationships and popular culture than politics, Schumer can go places Bee cannot with regard to addressing the everyday rape culture that is perpetuated by private citizens rather than public officials. However, Schumer has also rightfully been called out for racism in a way Bee has not. As Goltz (2015) explains, "Schumer's performative doing of femininity and disruption of sexism is particularly enabled in her body, in a manner that her doing of racism through her white feminine body . . . is limited and discursively directed" (277). Indeed, she is more likely to simply repeat stereotypes than to deconstruct them, as evinced by work and comments depicting Colombians as ruthless kidnappers (Snatched 2017), Latinas as crazy (when hosting the MTV Movie Awards in 2015), black and brown women as props in a rap video ("Milk, Milk, Lemonade," Inside Amy Schumer 2015), and black men as inarticulate and raised by their grandmothers (Comedy Central 2011).

Schumer's rape joke oeuvre also includes this inexcusably racist bit: "I used to date Hispanic guys, but now I prefer consensual!" (see Zinoman 2019). Even if she intended it ironically, the joke reinforces stereotypes that play into a long-standing tradition of scapegoating men of color for rape. Given the intertwined histories of racism, colonialism, slavery, mass incarceration, deportation, rape, and mainstream feminism itself, rape jokes that rely on racist paradigms reproduce those violent histories. The joke is, in fact, a quintessential example of hipster racism: the practice of someone in a dominant racial group making a derogatory comment about people in a historically disadvantaged racial/ethnic group under the guise of being ironic (Van Kerckhove 2007). The Guardian's Monica Heisey (2015) notes that 
"For such a keen observer of social norms and an effective satirist of the ways gender is complicated by them, Schumer has a shockingly large blind spot around race." Offering an example of the problematic conflation of mainstream feminism with antiracism, Schumer (@amyschumer) responded via Twitter on June 28, 2015, that she was a "devout feminist" and that people like Heisey, who critiqued her racial politics, should "put down your torches." The reference to torch-bearers bizarrely conjured members of white supremacist groups, who have used torches as symbols of racial intimidation in the United States since the Civil War (Bond 2017), while the sentiment revealed Schumer's unacknowledged white privilege.

As Schumer notes, she sometimes plays a "dumb white girl character on stage" (quoted in Gorenstein 2015). In that character she can, to some extent, take on the boy's club from the inside, telling raunchy, raucous jokes about sex while also going after many male-dominated institutions and everyday sexist norms. However, the ironic racism of that "dumb white girl character" is ambiguous and not clearly distinguishable from Amy Schumer in interviews, tweets, or writing. As blogger s. e. smith (2009) explains, despite the fact "people may ardently claim that they are not racist, the people who engage in hipster racism are overwhelmingly white and middle class, and they clearly have some unaddressed racial issues which are being subverted in their attempts to be edgy." Schumer's work is marred by hipster racism and is not radical so much as representative of where white feminism is. Both Schumer and white feminism can challenge - and are frequently challenged by-white men who resent the space women are attempting to claim. And both are also challenged by women of color, others whose identity coordinates are not dominant (queer and trans women, disabled women, poor women), and allies who insist that white women acknowledge the very forms of social privilege that provide access to mainstream audiences. Like many white feminists, Schumer has much work to do to be an ally to other women. Diversifying her writing staff and demonstrating substantially greater awareness of the racial implications of her jokes, films, sketches, and public remarks are two obvious steps she might take. One hopes she will do that work: when she hits her mark, she offers much-needed critique of how rape culture is often perpetuated by everyday and even well-intentioned people. That the same is true of racism and other forms of oppression is a lesson for all feminists.

\section{Lena Weissbrot: Unruly feminist satire and the myth of the black male rapist}

Our final case study involves a rap video that addresses rape culture in a complicated knot of gender, race, cultural symbolism, and satire. In "Garnet \& 
Gold," Lena Weissbrot presents an arresting critique of rape culture, pushing that critique far more aggressively than either Bee or Schumer. ${ }^{3}$ In this case, Weissbrot, who identifies as white and Latina, created her own lowbudget music video, which has been distributed only online. When she was an undergraduate at Florida State University Weissbrot produced half a dozen rap videos under the ironically Orientalist - or hipster racist - name "Fellatia Geisha," as well as paintings and video games that comment on misogyny. She does not have a platform anywhere near as large as that of Bee or Schumer, though her status as an independent artist makes it easier for her to transgress cultural boundaries. ${ }^{4}$

In the "Dicksclaimer" her video opens with, Weissbrot states, "I do NOT want to fuck Jameis Winston. This song isn't even about him.” The song is nevertheless about the Winston case at Florida State University (FSU) and the extraordinary mishandling of the case. Winston, who is African American, was a star quarterback on the university's football team (the Seminoles) and the winner of the Heisman Memorial Trophy (awarded annually to an outstanding player in US college football). He was accused of rape by a fellow FSU student in late 2012 but was never questioned by the local police. A New York Times investigation concluded that "there was virtually no investigation at all, either by the police or the university" (Bogdanich 2014). Winston was cleared to continue playing for the rest of football season, and the alleged victim dropped out of school after being harassed and subjected to death threats in response to her accusation. She later sued the university for Title IX violations and sued Winston himself after he was drafted by a professional football team. Both cases were settled in her favor, though no wrongdoing was admitted (Carpenter 2016; Payne 2016).

In much of her "Garnet \& Gold" video Weissbrot appears dressed in an FSU tank top, short shorts, and knee socks while she sings and struts across stadium bleachers, several other dancers at her side. In her study of betterknown comics, Mizejewski (2014) contends, "The status of the female body itself - its visibility, availability, and presumed heterosexuality - is intrinsic to women's comedy even at its most transgressive" (19). The female body

${ }^{3}$ All quotations from "Garnet \& Gold" are taken from a YouTube video posted by "Fellatia Geisha” (Lena Weissbort), produced by Ray Benton. The video was accessed on June 16, 2016, but is no longer available online.

${ }^{4}$ We chose to consider Weissbrot, an independent student artist, alongside established figures such as Bee and Schumer (who work with teams of writers, editors, and producers), as we were attracted to contemporary examples of feminist satire of sexual assault; in 2015 Weissbrot received national news coverage for her related work. Weissbrot, both younger and lesserknown than Bee and Schumer, approached rape culture with a rawness and raunchiness that are not possible for Bee and Schumer in their television programs. 
is on display far more overtly here than in our other case studies; Weissbrot thrusts her hips, uses her fingers and tongue to recreate a popular representation of oral sex, and sexily performs the "tomahawk chop" (which originated and remains popular at FSU despite its controversial co-optation of $\mathrm{Na}$ tive American culture). Rivulets of red and yellow paint drip down her legs, disrupting the familiar visuals of a fetishized cheerleader-like figure. Clearly evoking menstrual blood and ketchup and mustard, the liquids are also the university's colors, garnet and gold. Playing on the popular FSU expression, "I bleed garnet and gold," the chorus of Weissbrot's song is "Bitch, I bleed garnet and gold. I got the harness, you got the hole. GO NOLES! GO NOLES! GO NOLES!" Intercut with the stadium footage are shots of Weissbrot grinding her pelvis on the campus's oversized bronze statues of football players. In other shots, she wears a makeshift strap-on penis, fashioned alternately out of a Heisman statue or what appears to be a bronze crab leg (in reference to Winston's citation for shoplifting a bag of crab legs from a supermarket). Throughout, she raps about using the strap-on to penetrate Winston in a symbolic rape-revenge fantasy while also indicating that she has larger targets: the university as well as football culture as a whole.

In its examination of the extremely limited investigation into the case, the New York Times draws attention to how the timing of the charges against Winston diminished the likelihood of an actual investigation: "If Florida State was going to ascend to the national championship game . . . it would do so on the arm and poise of Jameis Winston." The Times also notes, "it would be difficult to overstate the importance of football to Florida State and its hometown," explaining that the 2013 championship season when the charges against Winston were made public "generated millions of dollars for the athletic department and city businesses, and favorable publicity beyond measure" (Bogdanich 2014). Winston's symbolic value to the university as a national champion, his financial value to the athletic department and the city of Tallahassee, and the veneration with which fans regarded the Seminoles effectively foreclosed the possibility of an investigation that might have brought the accuser justice, or allowed Winston to clear his name.

In her response to the noninvestigation, Weissbrot raps, "I'm still reacting to the action that wasn't taken" while strutting by an iconic FSU stained glass window depicting a crowd of football fans. In split screen with her dancing, we briefly see what appear to be FSU pamphlets on sexual assault and consent, clearly pointing to what she sees as the institution's hypocrisy. She also likens football at the school to religion, rapping:

Elite athlete privilege Is like next to religion 
Worship the pig skin

Your face on Jesus' body

They see you like God, see

As she sings, she profanes quasi-religious symbols, like the stained glass windows and the oversize bronze statues. Weissbrot points to the way football is treated reverentially and religiously at FSU (and in American culture as a whole) and deliberately attempts to tear it down, using her body to hump the statue and disrespect sports culture. Unlike in "Football Town Nights," in which Schumer herself is a minor character, in "Garnet \& Gold" Weissbrot is dead center, confronting a specific real-life event. Also in contrast to Schumer's performance in "Football Town Nights," in no way does Weissbrot address rape culture in a gentle or polite fashion, task others with castigating her targets, or provide her audience with tension-relieving jokes.

The video is exuberantly carnivalesque. A signature element of the carnivalesque style is grotesque realism, involving exaggerated emphasis on bodily functions, particularly those of the lower half of the body. As Mikhail Bakhtin (1984) explains, the carnivalesque is about "degradation, that is, the lowering of all that is high, spiritual, ideal, abstract" (19). Although Bakhtin himself does not focus on gender, theorists including Mizejewski have noted that there is a "cultural history of the lower female body as dirtier and more disgusting than the lower male body" $(2014,101)$. Weissbrot deliberately flouts the social imperative for women to keep menstruation contained and hidden from mention, at one point dipping her fingers in the liquid on her legs to wipe the colors across her cheeks like war paint while rapping, "I'm in you like OB tampons, national champions."

Kathleen Rowe (1995) has written extensively on "the disruptive power of the unruly woman" (54) and explains that "women are expected to keep not only their bodies but their utterances unobtrusive" (64). Women are often despised when they take up too much space or draw excessive attention, as they are flouting the strictures of social control. Though socially scorned, the unruly woman powerfully asserts female agency. Weissbrot takes up space. She is loud and vulgar, and she claims her own sexual power, campily brandishing a strap-on and vamping for the camera. She is staging her own form of sexual aggression and power, turning the tables on the accused rapist and on the institutional culture that protects him. She boasts, "I'm raping Jameis Winston. With the Heisman trophy. Asking why can't he just blow me." Hers is an aggressive, in-your-face feminist grotesque. At the end of the video, Weissbrot runs from the stained-glass doors and appears to jump off an upper story of the FSU stadium, rolling away like an action-movie 
hero as a hastily matted stock-footage explosion indicates a bomb has detonated. It would never be mistaken for real violence, but the symbolic violence is unmissable.

In her 2013 video "Split Lip," Weissbrot talks about getting death threats due to her videos, many of which address rape culture and other issues women face in a male-dominated world. Unsurprisingly, there are masses of vitriolic comments underneath Weissbrot's videos. The content of the negative comments on "Garnet \& Gold" are similar to responses to Bee's and Schumer's work on rape culture. However, there are many more referring to Weissbrot as "disgusting" (despite her conventionally attractive appearance), along with ample uses of "crazy" and "bitch," consistent with Rowe's description of how "unruly women" tend to be perceived. Nevertheless, there are comments commending Weissbrot on her courage and applauding her analysis. For those unfazed by her artistic choices and interested in hearing her critique, there is pleasure in witnessing the breaking of taboos and in vicariously experiencing her jouissance in desecrating football culture, as well as, perhaps, a feeling of righteous symbolic vengeance.

Weissbrot's video prompts the question: Does she, or can she, distinguish between the black man accused of rape and the larger culture she, as a whitepresenting woman, critiques in her rape-revenge feminist narrative? That she employs the traditionally black cultural form of a rap video further complicates the potential pleasure, as does a member of her multiracial and multigender mini-cheerleading squad seemingly ironically sporting a Native American headdress. Weissbrot decorates her face with "war paint" and satirically performs the "tomahawk chop" at FSU, where football fans regularly engage in what Dave Zirin (2014) calls "mass interactive minstrelsy." All of this amounts to an extremely complicated amalgam of identities, histories, and cultural symbols. Such complications are not uncommon in music videos, but Weissbrot's work differs from that genre in its commitment to critique rather than commerce.

What Weissbrot does in "Garnet \& Gold," as a biracial millennial feminist who traffics in popular and digital culture signifiers, is rape the seemingly sacred culture of college football in a video that is more carnivalesque performance art than mainstream comedy. In so doing, she profanes the unprofanable, a responsibility Giorgio Agamben describes as "the political task of the coming generation" $(2007,92)$. To do so without reproducing historical fears of the black male rapist or overlooking the intersectional challenges disadvantaged women face in addressing sexual violence-which is to say, to recognize and address the many axes that inform rape cultureis the task of this generation of antirape theorists and feminists. 


\section{Conclusion}

In December 2017, just as the \#MeToo campaign had peaked, Saturday Night Live aired a satirical bubblegum-pop video titled "Welcome to Hell." In the sketch, the female performers appear as infantilized male fantasies in pastel baby-doll dresses with candy-ring accessories. Instead of belting out a pop ode to their crushes, however, the women explain that none of the bummer revelations about predatory men are actually news. Rather, women have been navigating the constant threat of predation for centuries. Like Sykes in "Detachable Pussy," the women note how sexual violence impacts women's everyday lives, ruining everything from parking to walking, drinking to ponytails, and especially vans. Mimicking a centuries-old defense of those accused of sexual violence, performer Kate McKinnon coos, "I guess it b-b-begs the question, woah, why didn't you say something, baby girl?” To which Saoirse Ronan responds, "Well dang devil daddy, we definitely did. For hundreds of years."

The sketch is a telling artifact of the moment. Saturday Night Live typically plays it quite safe, rarely offering truly insightful satire that might upset a swath of its mainstream audience (Day and Thompson 2012), but this sketch generated attention for its forthright take on the reality of sexual violence. As we have noted, outspoken female performers are seizing the microphone to an unprecedented degree, bringing with them topics and perspectives long absent from American popular culture. Halfway through the song, Leslie Jones, who joined the SNL cast in 2014 after the show was pressured to hire black women, enters the frame. She asks the other (white) performers, "You do know that it is like a million times worse for a woman of color, right?" to which they all enthusiastically agree. As we have seen, the racial dimensions of rape culture are absent in the cable television and YouTube videos we explored, and thus it is notable for a network television sketch to insert this racial dimension into the mainstream discussion. However, the moment of racial awareness is brief, incomplete, and largely undermined by the way the video promptly recenters white women's experiences and relegates women of color to backup dancers and walk-on parts. There is no explication of Jones's question of why rape culture is "like a million times worse for women of color," and this small gesture cannot compensate for the voices and perspectives still missing from the discussion.

Much of the pleasure in "Welcome to Hell" - like the material produced by Bee, Schumer, and Weissbrot - is the satisfaction in witnessing rape acknowledged at all, and particularly in seeing aspects of rape culture deconstructed with anger and wit. As some of our case studies illustrate, satire is a strategy for shifting public conversation: changing the terms we use to conceptualize 
an issue or pushing otherwise niche issues into the mainstream. However, the way those issues are framed is important.

As was the case with \#MeToo, those who gain public recognition for speaking out against sexual violence-on social media platforms, in mainstream venues, or through comedic performances - are almost always privileged women. That their less privileged feminist counterparts were doing related work earlier (sometimes under the same name, in the case of \#MeToo) typically only comes to national attention later, and with pressure from other groups. This trend is often regarded as positive: women who have ascended to platforms through which they can amplify and mainstream important discussions (through satire or other forms of communication) create space for more nuanced understandings and discussions of those issues. However, the trend tends to result in the refrain that "it's so much worse for women of color" without further analysis, or any substantive alteration to the singleaxis framework through which rape culture has historically been understood.

As we have seen, a satirist can challenge dimensions of oppressive systems such as rape culture while neglecting, and in some cases reinforcing, others. Bee, Schumer, and Weissbrot chip away at rape culture by exposing many of the myths that sustain it, but they overlook its intersectional dimensions, including how the combined effects of sexism and racism leave women of color particularly susceptible to sexual violence, and that women of color live with cultural and institutional barriers to reporting-or successfully prosecuting - that extend beyond what most (cisgender heterosexual) white women experience. They also leave unchallenged, and in some cases feed into, the cultural assumption, and rape myth, that men of color are more likely to rape. As Davis noted more than three decades ago, an inclusive feminist critique "must not only defend women of color, but the many victims of the racist manipulation of the rape charge as well" $(1983,201)$. When Schumer jokes about Hispanics and nonconsensual sex, and Weissbrot takes symbolic revenge on a black athlete (rather than just on his university and police inaction), both in fact play into a long-standing tradition of scapegoating men of color with sexual violence scripts. Bee avoids doing so but also does not draw attention to rape culture's racial dimensions, including who is presumed innocent or guilty and with what consequences.

As our case studies illustrate, we must insist on intersectional feminismand intersectional satire - and for more diverse voices and perspectives to be given a microphone. The work of exposing racism, sexism, rape culture, and other overlapping expressions of power should not fall solely on those feminists, performers, and/or scholars who experience their effects most directly. We have begun to illuminate the way rape culture is satirized for mainstream audiences and to expose how a single-axis understanding of rape culture is 
too often the result of a single-axis understanding of feminism. More research is needed, as is more intersectional feminist comedy. Although neither can vanquish rape culture alone, collective voices can erode the tired cultural assumptions and challenge political practices that have long sustained it, while creating powerful counternarratives.

School of Humanities, Arts, and Cultural Studies

Hampshire College (Greene)

Department of English and Cultural Studies

Bryant University (Day)

\section{References}

Agamben, Giorgio. 2007. Profanations. New York: Zone.

Anderson, Karrin Vasby. 2012. "Tosh, Rape Culture, and the Number Five." The New Agenda. Blog post, July 13. http://www.thenewagenda.net/2012/07/13 /tosh-rape-culture-and-the-number-five/.

Bakhtin, Mikhail Mikhaǐlovich. 1984. Rabelais and His World. Bloomington: Indiana University Press.

Bell, Kris M. 2016. "Colorblind Feminism." The Random Mind. Blog post, January 6. https://krismbell.com/2016/01/06/colorblind-feminism-2/.

Bogdanich, Walt. 2014. "A Star Player Accused, and a Flawed Rape Investigation." New York Times, April 16. https://www.nytimes.com/interactive/2014/04/16 /sports/errors-in-inquiry-on-rape-allegations-against-fsu-jameis-winston.html.

Bond, Sarah. 2017. "A Short History of Torches and Intimidation.” Forbes, August 15. https://www.forbes.com/sites/drsarahbond/2017/08/15/a-short-history-of -torches-and-intimidation/\#512a6b467629.

Brand, Peg. 2006. "Feminist Art Epistemologies: Understanding Feminist Art." Hypatia 21(3):166-89.

Bullock, Penn. 2016. “Transcript: Donald Trump's Taped Comments about Women.” New York Times, October 8. https://www.nytimes.com/2016/10/08/us /donald-trump-tape-transcript.html.

Burton, Sarah. 2015. "Samantha Bee Created a Rape Threatline for Trolls and It's Genius." BuzzFeed, December 11. https://www.buzzfeed.com/sarahburton /samantha-bee-created-a-rape-threatline-for-trolls-and-its-ge.

Bush, Billy. 2017. "Billy Bush: Yes, Donald Trump, You Said That.” New York Times, December 3. https://www.nytimes.com/2017/12/03/opinion/billy-bush -trump-access-hollywood-tape.html?search-input-2= bush + crass + stand-up + act.

Cai, Weiyi, and Scott Clement. 2016. "What Americans Think about Feminism Today." Washington Post, January 27. https://www.washingtonpost.com/graphics/national /feminism-project/poll/. 
Carpenter, Les. 2016. "FSU Reaches \$950,000 Settlement with Woman Who Accused Jameis Winston of Rape." The Guardian, January 25. http://www.theguardian .com/sport/2016/jan/25/fsu-reaches-950000-settlement-with-woman-who -accused-jameis-winston-of.

Comedy Central Roast of Charlie Sheen. 2011. Directed by Joel Gallen. Digital download, January 2018.

Connecticut Alliance to End Sexual Violence. n.d. "Women of Color and Sexual Assault." https://endsexualviolencect.org/resources/get-the-facts/woc-stats/.

Crenshaw, Kimberlé. 1989. "Demarginalizing the Intersection of Race and Sex: A Black Feminist Critique of Antidiscrimination Doctrine, Feminist Theory, and Antiracist Politics." University of Chicago Legal Forum 1989: 139-67.

_. 2017. "Kimberlé Crenshaw on Intersectionality, More Than Two Decades Later." Columbia Law School, June 8. http://www.law.columbia.edu/pt-br /news/2017/06/kimberle-crenshaw-intersectionality.

Davis, Angela Y. 1983. Women, Race, and Class. New York: Vintage.

Day, Amber, and Ethan Thompson. 2012. "Live from New York, It's the Fake News! Saturday Night Live and the (Non)politics of Parody." Popular Communication 10(1-2):170-82.

Ferreday, Debra. 2015. "Game of Thrones, Rape Culture, and Feminist Fandom." Australian Feminist Studies 30(83):21-36.

Finley, Jessyka. 2016. “Black Women's Satire as (Black) Postmodern Performance.” Studies in American Humor 2(2):236-65.

Ford, Thomas E. 2000. "Effects of Sexist Humor on Tolerance of Sexist Events." Personality and Social Psychology Bulletin 26(9):1094-1107.

Ford, Thomas E., Christine F. Boxer, Jacob Armstrong, and Jessica R. Edel. 2008. "More Than 'Just a Joke': The Prejudice-Releasing Function of Sexist Humor." Personality and Social Psychology Bulletin 34(2):159-70.

Full Frontal with Samantha Bee. 2016. Episode 7, "American Atheists at CPAC," aired on March 21.

Goltz, Dustin Bradley. 2015. "Ironic Performativity: Amy Schumer's Big (White) Balls." Text and Performance Quarterly 35(4):266-85.

Gorenstein, Colin. 2015. "Amy Schumer Apologizes for Her Racially Insensitive Jokes: 'I Am Taking Responsibility and Hope I Haven’t Hurt Anyone.' Salon, July 7. https://www.salon.com/2015/07/07/amy_schumer_apologizes_for _her_racially_insensitive_jokes_i_am_taking_responsibility_and_hope_i_haven \%E2\%80\%99t_hurt_anyone/.

Gray, Jonathan, Jeffrey Jones, and Ethan Thompson, eds. 2009. Satire TV: Politics and Comedy in the Post-network Era. New York: New York University Press.

Haggins, Bambi. 2017. "Moms Mabley and Wanda Sykes: 'I'm a Be Me.' " In Hysterical! Women in American Comedy, edited by Linda Mizejewski and Victoria Sturtevant, 207-32. Austin: University of Texas Press.

Handy, Bruce. 2016. "Amy Schumer Is Rich, Famous, and in Love: Can She Keep Her Edge?” HWD (Vanity Fair), May. https://www.vanityfair.com/hollywood /2016/04/amy-schumer-cover-story. 
Heisey, Monica. 2015. “Amy Schumer: Comedy's Viral Queen.” The Guardian, June 28. https://www.theguardian.com/tv-and-radio/2015/jun/28/amy-schumer -comedys-viral-queen.

Hitchens, Christopher. 2007. "Why Women Aren’t Funny." Vanity Fair, January. https://www.vanityfair.com/culture/2007/01/hitchens200701.

Human Rights Campaign. n.d. "Sexual Assault and the LGBTQ Community." https://www.hrc.org/resources/sexual-assault-and-the-lgbt-community/.

Inside Amy Schumer. 2014. Episode 12, "I'm So Bad," aired on April 8. . 2015. Episode 21, "Last Fuckable Day," aired on April 21.

Jones, Alice. 2014. “The Week in Comedy: Jerry Seinfeld's Race Rant Is No Laughing Matter." The Independent, February 7. https://www.independent.co.uk/arts -entertainment/comedy/features/the-week-in-comedy-jerry-seinfelds-race-rant -is-no-laughing-matter-9113136.html.

Kelly, Annie. 2017. "The Alt-Right: Reactionary Rehabilitation for White Masculinity; US Alt-Right Extremism Is a Logical Consequence of Mainstream NeoConservatism." Soundings 66 (August): 68-78.

Levitz, Eric. 2016. "Expanding Incarceration Is Not the Best Way to Fight Rape Culture." New York, August 31. http://nymag.com/daily/intelligencer/2016/08 /incarceration-is-not-the-best-way-to-fight-rape-culture.html.

Loza, Susana. 2014. "Hashtag Feminism, \#SolidarityIsForWhiteWomen, and the Other \#FemFuture." Ada, no. 5 (July). https://adanewmedia.org/2014/07/issue5-loza/.

Mantilla, Karla. 2013. "Gendertrolling: Misogyny Adapts to New Media." Feminist Studies 39(2):563-70.

Mizejewski, Linda. 2014. Pretty/Funny: Women Comedians and Body Politics. Austin: University of Texas Press.

Okeowo, Alexis. 2017. "The Provocateur behind Beyoncé, Rihanna, and Issa Rae." New Yorker, March 6. https://www.newyorker.com/magazine/2017/03/06 /the-provocateur-behind-beyonce-rihanna-and-issa-rae.

Paskin, Willa. 2014. "The F Word: Inside Amy Schumer, the Most Sneakily Feminist Show on TV." Slate, April 1. http://www.slate.com/articles/arts/television /2014/04/inside_amy_schumer_season_2_the_most_feminist_show_on_television .html.

Payne, Marissa. 2016. "Jameis Winston Settles Civil Lawsuit with Accuser in Sexual Assault Case." Washington Post, December 15. https://www.washingtonpost .com/news/early-lead/wp/2016/12/15/jameis-winston-settles-civil-lawsuit -with-accuser-in-sexual-assault-case/.

Pérez, Raúl, and Viveca S. Greene. 2016. "Debating Rape Jokes vs. Rape Culture: Framing and Counter-framing Misogynistic Comedy.” Social Semiotics 26(3):26582.

Ridgeway, Shannon. 2014. "25 Everyday Examples of Rape Culture.” Everyday Feminism, March 10. https://everydayfeminism.com/2014/03/examples-of-rape -culture/.

Romero-Sánchez, Mónica, Mercedes Durán, Hugo Carretero-Dios, Jesús L. Megías, and Miguel Moya. 2010. "Exposure to Sexist Humor and Rape Proclivity: The 
Moderator Effect of Aversiveness Ratings." Journal of Interpersonal Violence 25(12):2339-50.

Rowe, Kathleen. 1995. The Unruly Woman: Gender and the Genres of Laughter. Austin: University of Texas Press.

Saturday Night Live. 2017. Episode 9, "Welcome to Hell," aired on December 2. Schmiedt, Nastassja, and A. Lea Roth. 2015. "Hunting for the Perfect Victim." Huffington Post, November 23. https://www.huffingtonpost.com/nastassja -schmiedt/hunting-for-the-perfect-v_b_8626034.html.

smith, s. e. 2009. “Hipster Racism.” This Ain't Livin'. Blog post, July 16. http:// meloukhia.net/2009/07/hipster_racism.html.

Snatched. 2017. Directed by Jonathan Levine. Starring Amy Schumer and Goldie Hawn. Los Angeles: Twentieth-Century Fox.

“Split Lip.” 2013. Video, Fellatia Geisha (Lena Weissbrot), produced by Javie V, December 19. https://www.youtube.com/watch?v=ueTndCwbli0.

Stamper, Kory. 2018. "A Brief, Convoluted History of the Word 'Intersectionality." " The Cut (New York), March 9. https://www.thecut.com/2018/03/a-brief -convoluted-history-of-the-word-intersectionality.html.

Test, George Austin. 1991. Satire: Spirit and Art. Tampa: University of South Florida Press.

Thomae, Manuela, and G. Tendayi Viki. 2013. "Why Did the Woman Cross the Road? The Effect of Sexist Humor on Men's Rape Proclivity." Journal of Social, Evolutionary, and Cultural Psychology 7(23):250-69.

Tomlinson, Barbara. 2010. Feminism and Affect at the Scene of Argument: Beyond the Trope of the Angry Feminist. Philadelphia: Temple University Press.

Traister, Rebecca. 2016. "Smirking in the Boys' Room." The Cut (New York), January 25. https://www.thecut.com/2016/01/samantha-bee-full-frontal-c-v-r.html.

VanDerWerff, Todd. 2016. "Samantha Bee Is Going Where Jon Stewart and John Oliver Never Did." Vox, July 3. https://www.vox.com/2016/7/3/12076800 /samantha-bee-full-frontal-tbs-review-brexit.

Van Kerckhove, Carmen. 2007. "The 10 Biggest Race and Pop Culture Trends of 2006.” New/Demographic. http://www.mauracullen.com/wp-content/uploads /2010/11/Top-Trends-in-Race-and-Pop-Culture.pdf.

Vanstone, Ellen. 2017. "Plan Bee." Globe and Mail, January 6. https://www .theglobeandmail.com/arts/television/full-frontals-samantha-bee-may-be-americas -best-weapon-againsttrump/article33526438/.

Wanda Sykes: Sick and Tired. 2006. Directed by Michael Drumm. New York: HBO.

Yancy, George. 2000. "Feminism and the Subtext of Whiteness: Black Women's Experiences as a Site of Identity Formation and Contestation of Whiteness." Western Journal of Black Studies 24(3):156-66.

Zinoman, Jason. 2019. “Amy Schumer Doesn't Care What You Think (That Much).” New York Times, March 13. https://www.nytimes.com/2019/03/13/arts/television /amy-schumer-growing-netflix.html.

Zirin, Dave. 2014. "The Florida State Seminoles: The Champions of Racist Mascots." The Nation, January 7. https://www.thenation.com/article/florida-state -seminoles-champions-racist-mascots/. 